\title{
教育セミナー 2
}

\section{これまで見逃されていた好塩基球の存在意義と 病態形成における役割 一山椒は小粒でもぴりりと辛いー}

東京医科歯科大学大学院医歯学総合研究科 免疫アレルギー学分野

\author{
烏 山
}

好塩基球は顆粒球の一種で, 1879 年にPaul Ehrlichによって初めてその存在が記載されたが，その後 長い間，生体内での役割・存在意義に関してほとんど解明が進んでいなかった，好塩基球は，末梢血 白血球のわずか $0.5 \%$ 占めるに過ぎない極少血球細胞集団であり，また好塩基性分泌顆粒，高親和性 IgE 受容体 FceRI の発現，ヒスタミンを含むケミカル・メディエーターの分泌などマスト細胞との類似 点が多いことから，マスト細胞のバックアップ的存在あるいは前駆細胞と見なされ，マスト細胞に比 べきわめて影の薄い存在であった。一方，解剖学的観点からすると，マス卜細胞が末梢組織中に定住 しているのに対し，好塩基球は末梢血中を循環するといった局在の違いは明らかで，好塩基球が生体 内でマスト細胞とは異なるユニークな役割を担っている可能性が示唆されていた．事実，この数年の 間に立て続けに, 生体内におけるアレルギー反応や免疫制御において好塩基球が極めて重要な役割を 果たしていることが報告されて，これまで日陰者扱いされていた好塩基球が，にわかに注目を集める ようになった，本講演では，私たちが最近見いだした，好塩基球による「慢性アレルギー炎症誘導」 と「寄生虫感染防御」を中心にして, 生体内における好塩基球のユニークな役割について討議したい. 